\title{
A Study on a Root Canal Filling, Containing Thymol in High Concentration
}

\author{
Sen Higashi ${ }^{1}$, Tomoko Ohsumi ${ }^{1}$, Yukiko Koga', \\ Kayoko Kuroki ${ }^{1}$ and Hiroshi Fukuyama ${ }^{2}$ \\ ${ }^{1}$ Division of Applied Pharmacology, \\ ${ }^{2}$ Division of Oral Pathology, \\ Kyushu Dental College, Kitakyushu, Japan \\ E-mail address: sen@kyu-dent.ac.jp
}

Received May 9, 2005.

Accepted June 22, 2005.

\begin{abstract}
Safety evaluation was made on Biological canal paste (BCP), one of newly developed endodontic pastes used for Ultrasonic Bio-Mechanical Obturation System. BCP was characteristic of a high content of thymol to show extreme antimicrobic action. The basic biological tests on cytotoxicity, systemic toxicity, mutagenicity and dermal sensitization were carried out in this study. On potency of cell growth inhibition in vitro, BCP was as same as Canals- $\mathrm{N}^{\circledR}$ and much less than Canals ${ }^{\circledR}$. As neither death nor toxic syndrome in mice was found from administration of $\mathrm{BCP}$ in oral maximal dose of $1.0 \mathrm{mg} / \mathrm{kg}$, it was estimated that $\mathrm{LD}_{50}$ of $\mathrm{BCP}$ should be not less than the value of 'slightly toxic' classified by Deichmann. BCP showed negative results in mutagenicity examined by Ames test, and also in delayed type allergenicity by Adjuvant and patch test. From the above it was suggested that BCP was possibly safe so far as it was used properly for dental therapy.
\end{abstract}

Key words: Biological canal paste/Thymol/Toxicity

\section{INTRODUCTION}

Volatile oils such as clove oil, eucalyptus oil, mentha oil, and cinnamic oil are made of each original aromatic vegetable and called essential oils. They have been used for medical drugs since more than 400 years ago $^{1,2}$. Some essential oils and also chemicals contained in them were introduced to dental therapy, and they played important roles showing various effects of disinfection, anti-inflammation and cyto-activation, as well as aromatic effect ${ }^{1,3-5)}$.

Especially thymol, a main constituent of thyme oil, mosla oil, etc., is to be more appreciated for its excellent sterilizing action ${ }^{6)}$. A newly developed root filling technique with application of thymol preparations was named Ultrasonic Bio-Mechanical Obturation System and introduced to clinical practice, resulting in a considerably good clinical 
progress $^{7,8)}$. Two endodontic pastes of respective formula containing thymol in a high concentration were used there; one paste was a pulp capping named Biological canal paste $(\mathrm{BCP})$, and the other was a root canal filling named Mechanical canal paste (MCP) ${ }^{7)}$. Intention of the composition of $\mathrm{BCP}$ was to bring the lesion a better calcification, which was given not only by a proper stimulation but also by a remarkable and lasting sterilization.

No study was made on their toxicity for clinical application of the thymol-rich pastes. Matters of concern had been their therapeutic effect and physical properties to be improved in manipulation, obturation, endurance and so on. An attempt was made in this paper to evaluate safety of BCP on the basis of our studies of cytotoxicity in vitro, single dose toxicity, mutagenicity and dermal sensitization.

\section{MATERIALS AND METHODS}

\section{Test compound}

Biological canal paste (BCP, Nihon Shikayakuhin Co. Ltd., Japan) was a test sample used for all experiments. Composition of $\mathrm{BCP}^{7)}$ is shown in Table 1.

\section{Cytotoxicity test}

Two commercial root canal fillings were tested as positive control of the test: BCP was compared with an eugenol-containing paste, Canals ${ }^{\circledR}$ (Showa Yakuhin Kako, Japan) and an eugenol-free paste, Canals- $\mathrm{N}^{\circledR}$ (Showa Yakuhin Kako, Japan), on inhibition of cell growth.

Mouse L-929 cells (NCTC clone 929, Dainippon Pharmaceutical, Japan) were grown in plastic tissue culture flasks (Falcon, USA) with Eagle's minimum essential medium (MEM-1, Nissui Pharmaceutical, Japan) supplemented with $3 \%$ fetal bovine serum (FBS, Difco, USA) $0.17 \%$ tryptose phosphate broth (Difco, USA) and $2 \%$ L-glutamine (Wako Pure Chemical, Japan).

Immediately after mixing of powder and base to extract the elution during harding, $\mathrm{BCP}$

Table 1 Composition of BCP

\begin{tabular}{llr}
\hline \multicolumn{1}{c}{ Component } & $\%$ \\
\hline \multirow{2}{*}{ Powder } & Calcium hydroxide & 30.00 \\
& Barium sulfate & 25.00 \\
& Bithmuth oxycarbonate & 25.00 \\
& Zinc oxide & 20.00 \\
\hline \multirow{2}{*}{ Base } & MCT* & 63.00 \\
& Yellow bees wax & 15.00 \\
& Rosin & 6.00 \\
& Thymol & 16.00 \\
\hline
\end{tabular}

* MCT : middle chain fatty acid triglyceride

Powder and base are mixed just before application in the ratio of $0.85 \mathrm{~g}$ to $0.5 \mathrm{ml}$ 
paste was added to culture medium and stirred well for 2 minutes by an automatic mixer. Then the medium with BCP was filtered $(0.45 \mu \mathrm{m}$, Millipore, Japan), and diluted in the original medium to various concentrations of BCP. Cells were seeded in culture dishes ( $35 \mathrm{~mm} \phi$, Falcon, USA), and 5 hours after incubation, the medium was exchanged to the fresh one with BCP. After 7 day cultivation, adherent cells were fixed to dish and stained with $0.1 \mathrm{M}$ crystal violet in $0.1 \mathrm{M}$ citric acid. Inhibition of cell growth was measured with Monocelator (Olympus, Japan) in comparison with control growth in BCP-free medium. Calculation of the percentage of inhibition was based on the control cell adhesion ${ }^{11)}$.

\section{Single dose toxicity test ${ }^{10,12)}$}

ICR strain specific pathogen free male mice (4 weeks old, Charles River Japan, Inc.) were used. Test was started after 1 week prebreeding. Mice were bred in plastic cages in a barrier sustained room. Food and water were available ad libitum.

Mice were forcibly given BCP orally in dose of $1.0 \mathrm{~g} / \mathrm{kg}(160 \mathrm{mg}$ thymol $/ \mathrm{kg})$ with sonde. Freshly mixed BCP paste was diluted with olive oil. The control group was given olive oil in dose of $0.1 \mathrm{ml} / 10 \mathrm{~g}$ body weight instead of BCP. The experimental period was continued for 14 days after single administration. Mortality and general signs were observed and body weights were measured daily. Dietary consumption (D.C.) and water consumption (W.C.) were measured once a day per group through the experiment period and divided the number of mice. Dietary efficiency was calculated from the amount of gain in weight divided by amount of D.C. Gross observation on organs and tissues of all mice was performed at the end of the experimental period. Liver and kidneys were excised from all animals for weighing and for histopathological examination. After wet organ weights were measured in absolute value and then ratio to body weight was calculated, organs were prepared by the routine method of histological studies. Any other organ found macroscopic changes at necroscopy was also given histopathological examinations.

\section{Mutagenicity test ${ }^{132}$}

Mutation assay was carried out by preincubation method of modified Ames test by Yahagi $(1975)^{14,15)}$. The Salmonella typhimurium tester strains TA98 and TA100 (IFO14193 and IFO14194, Institute for Fermentation Osaka, Japan) were used to detect the induction of frameshift mutations and base pair substitutions in the presence of metabolically activating S9-mix (Oriental Yeast, Japan). Dimethyl sulfoxide (DMSO, Infinity pure reagent grade, Wako Pure Chemical, Japan) was used as a negative control and 2-aminoanthracene (Wako Pure Chemical, Japan) was used as a positive control. Freshly mixed BCP was diluted in physiological saline and filtered $(0.45 \mu \mathrm{m}$, Millipore, Japan) as described in cytotoxicity test. From preparatory experiment, BCP was tested in the concentrations from 0.01 to $100 \mathrm{mg} / \mathrm{plate}$.

\section{Dermal sensitization test}

The adjuvant and patch test was carried out as described by Sato et al. ${ }^{16)}$ and Katuta et 
Table 2 Evalution of skin reaction (scale for scoring)

(1) Erythema formation

$\begin{array}{ll}\text { None } & 0 \\ \text { Very slight } & 1 \\ \text { Well defined } & 2 \\ \text { Moderate to severe } & 3 \\ \text { Severe erythema to } & 4 \\ \text { slight eschar formation } & \end{array}$

(2) Edema formation

$\begin{array}{ll}\text { None } & 0 \\ \text { Slight } & 1 \\ \text { Moderate } & 2 \\ \text { Severe } & 3\end{array}$

Mean response $(M R)=\frac{\sum_{1}^{n}[(1)+(2)]}{\text { Total number of animals }}$

$a{ }^{17)}$ with use of clean male guinea pigs of Hartley strain (Kyudo Co. Japan), weighing c.a. $350 \mathrm{~g}$.

At the first stage of induction, on the first day, the shoulder region of animals was shaved and emulsified Freund's complete adjuvant was injected intradermally at the 4 corners, and lattice abrasion was made on the injection site. The BCP paste was applied in $50 \%$ to an adhesive plaster for patch test (Torii Pharmaceuticals Inc.) and covered with surgical drape (Steri-Drape, 3M) to fix in place for 24 hours. Similar procedures of abrasion and application of patches to the same sites were repeated on the following two days.

At the second stage of induction, on the 8 day, $10 \%$ of sodium lauryl sulfate in yellow petrolatum was applied. On the 9 day, the BCP paste at the same concentration used in the first stage of induction was spread on a piece of filter paper. The filter was applied on the same shoulder region with plastic adhesive tape (Blenderm, 3M) and left for 48 hours.

At the challenge stage, on the 22 day, after shaving flank region, BCP paste was applied on the skin with open patch. The concentrations of sample were 2.5, 10, 25 and $50 \%$. Acetone was used for a vehicle of $\mathrm{BCP}$ and then also for a negative control of the test. Positive control was $0.0001-0.1 \%$ Sudan I (Wako, Japan) in acetone. The site of challenge reaction was evaluated at 24 and 48 hours after application, in accordance with the scale for scoring of skin reaction (Table 2) and the total erythema and edema scores show the extent of reaction.

\section{Statistical analysis}

Data were presented as the mean \pm S.E.M. from 3 to 5 animals or 2 to 9 samples per group as indicated in the respective tables. Statistical analysis were performed using Student's t-test if appropriate or Welch's t-test. $\mathrm{P}$ values of $<0.05$ were considered as significant.

All animal experiments were performed with the approval of The Animal Care Committee of Kyushu Dental College. 


\section{RESULTS}

I Cytotoxicity test

Cytotoxicity of BCP, Canals- $\mathrm{N}^{\circledR}$ and Canals ${ }^{\circledR}$ is shown as the percentage of inhibition of cell growth on dish bottom (Fig. 1). Fifty percent inhibitory concentration $\left(\mathrm{IC}_{50}\right)$ was $6.9 \mathrm{mg} / \mathrm{ml}$ for $\mathrm{BCP}, 6.2 \mathrm{~g} / \mathrm{ml}$ for Canals- $\mathrm{N}^{\circledR}$ and $1.0 \mathrm{mg} / \mathrm{ml}$ for Canals ${ }^{\circledR}$. No significant difference was found between $\mathrm{BCP}$ and Canals- $\mathrm{N}^{\circledR}$. BCP was almost as same as Canals- $\mathrm{N}^{\circledR}$ and much less than Canals ${ }^{\circledR}$ on cytotoxicity potency.

\section{Single dose toxicity test}

No mouse died and showed abnormal behaviors and appearances such as piloerec-

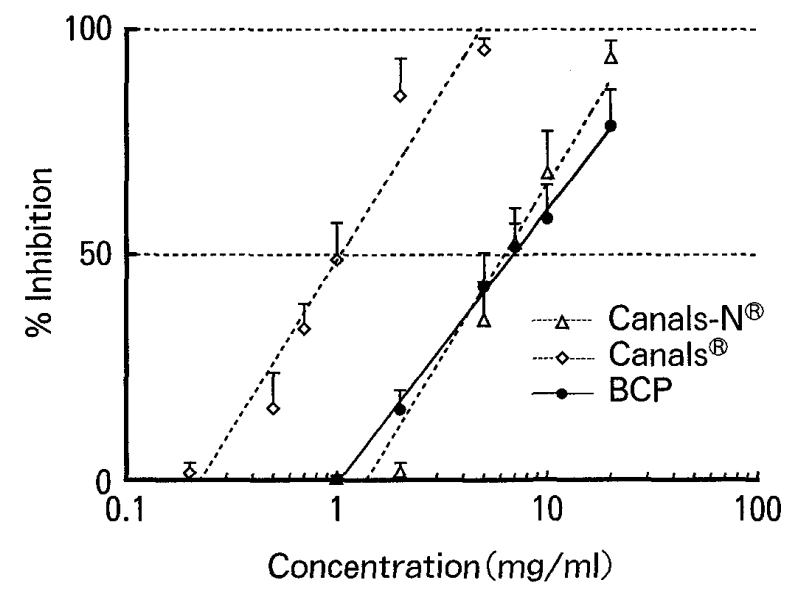

Fig. 1 Effect of BCP on the growth of L cells. The percentage of inhibition was based on control cell growth, values are mean \pm S.D. $(n=5)$ tion through the test period. There was no significant difference in body weight gain between BCP and control groups (Table 3). D.C. and W.C. were calculated in amount of per day and per body, and comparison was made on the mean value of each period between BCP and control groups. Animals given BCP showed no significant difference from the control in D.C. by period (Table 4) and in W.C. (Table 5) in any period of the observation.

Only relative organ weight of liver in BCP group decreased $(p<0.05)$, but on the other organ weights, no significant difference was seen from control (Table 6). In histopathological examination of liver and kidney, inflammatory infiltrating cells were seen partially and slightly in both groups.

Table 3 Change in body weight of male mice administered BCP in oral dose of $1.0 \mathrm{~g} / \mathrm{kg}$

\begin{tabular}{|c|c|c|c|}
\hline & & $\mathrm{BCP}$ & Control \\
\hline Number of mice at start & & 5 & 5 \\
\hline Death during experimental period & & 0 & 0 \\
\hline Number of mice at termination & & 5 & 5 \\
\hline \multirow{3}{*}{$\begin{array}{l}\text { Body weight.(B.W.,g士S.D.) } \\
\quad[\text { Ratio to } \operatorname{start}(\%)]\end{array}$} & At start & $27.3 \pm 0.8$ & $28.0 \pm 0.9$ \\
\hline & On 7 th day & $31.4 \pm 1.6[115]$ & $31.5 \pm 1.1[113]$ \\
\hline & At termination & $34.0 \pm 1.9[125]$ & $33.8 \pm 1.0[121]$ \\
\hline \multirow{3}{*}{$\begin{array}{l}\text { Gained B.W.,(g士S.D.) } \\
\quad[\text { Ratio to control }(\%)]\end{array}$} & 1 st $\sim 7$ th day & $4.1 \pm 1.0[117]$ & $3.5 \pm 0.5$ \\
\hline & 8 th $\sim 14$ th day & $2.6 \pm 0.7[87]$ & $2.0 \pm 0.6$ \\
\hline & 1 st $\sim 14$ th day & $6.7 \pm 1.4[116]$ & $5.8 \pm 0.6$ \\
\hline
\end{tabular}

Termination; 14 th day after administration

No significant difference is from control. 
Table 4 Change in dietary consumption and dietary efficiency of male mice administered BCP

\begin{tabular}{llccc}
\hline \hline & & $\begin{array}{c}\text { Dietary consumption } \\
\text { (g/body) }\end{array}$ & $\begin{array}{c}\text { Dietary efficiency } \\
\text { (\%) }\end{array}$ \\
& & For period & $\begin{array}{c}\text { Average for 1 day (mean } \pm \text { S.D.) } \\
\text { W.G./D.C. }\end{array}$ \\
\hline \multirow{3}{*}{ BCP } & From start to 7th day & 36.6 & $5.2 \pm 0.2$ & 11.2 \\
& From 8th day to termination & 34.7 & $5.0 \pm 0.1$ & 7.5 \\
& During experimental period & 71.3 & $5.1 \pm 0.2$ & 9.4 \\
\hline \multirow{3}{*}{ Control } & From start to 7th day & 34.4 & $4.9 \pm 0.2$ & 10.2 \\
& From 8th day to termination & 32.0 & $4.6 \pm 0.2$ & 6.3 \\
& During experimental period & 66.4 & $4.7 \pm 0.3$ & 8.7 \\
\hline
\end{tabular}

Termination; 14th day after administration

W.G.: Weight gain (g/body)

D.C.: Dietary consumption (g/body)

Table 5 Change in water consumption of male mice on oral administration of $\mathrm{BCP}$

(g/body)

\begin{tabular}{llcc}
\hline \hline & & For period & Average for 1 day (mean \pm S.D.) \\
\hline \multirow{3}{*}{ BCP } & From start to 7th day & 45.1 & $6.4 \pm 0.4$ \\
& From 8th day to termination & 42.1 & $6.0 \pm 0.1$ \\
& During experimental period & 87.2 & $6.2 \pm 0.4$ \\
\hline \multirow{3}{*}{ Control } & From start to 7th day & 51.6 & $7.4 \pm 0.6$ \\
& From 8th day to termination & 44.2 & $6.3 \pm 0.4$ \\
& During experimental period & 95.8 & $6.8 \pm 0.7$ \\
\hline
\end{tabular}

Termination; 14 th day after administration

Table 6 Absolute and relative organ weight in male mice on oral administration of BCP

(g/body)

\begin{tabular}{|c|c|c|c|c|c|c|c|}
\hline \multirow{3}{*}{\multicolumn{2}{|c|}{ No. of mice }} & \multicolumn{3}{|c|}{ Absolute organ weight $(\mathrm{g})$} & \multicolumn{3}{|c|}{ Relative organ weight (\%) } \\
\hline & & \multirow[t]{2}{*}{ Liver } & \multicolumn{2}{|c|}{ Kidney } & \multirow[t]{2}{*}{ Liver } & \multicolumn{2}{|c|}{ Kidney } \\
\hline & & & Right & Left & & Right & Left \\
\hline $\mathrm{BCP}$ & 5 & $1.80 \pm 0.16$ & $0.25 \pm 0.03$ & $0.25 \pm 0.03$ & $5.27 \pm 0.22^{*}$ & $0.73 \pm 0.08$ & $0.73 \pm 0.10$ \\
\hline Control & 5 & $1.95 \pm 0.17$ & $0.26 \pm 0.01$ & $0.27 \pm 0.02$ & $5.77 \pm 0.33$ & $0.77 \pm 0.03$ & $0.78 \pm 0.05$ \\
\hline
\end{tabular}

Values are mean \pm S.D.. *; Statistical difference is from control $(\mathrm{p}<0.05)$.

Relative $\operatorname{organ}$ weight $(\%)=$ Absolute $\operatorname{organ}$ weight $(\mathrm{g}) /$ body weight $(\mathrm{g}) \times 100$

III Mutagenicity test

Numbers of $\mathrm{His}^{+}$revertant colonies increased significantly in positive control (2-aminoanthracene) in both S. typhimurium TA100 (334\%) and TA98 strains (196\%) 
Table 7 Mutagenicity of $\mathrm{BCP}$ in $\mathrm{His}^{+}$revertant colonies of Salmonella typhimurium TA98 and TA100

\begin{tabular}{|c|c|c|c|}
\hline & Concentration & \multicolumn{2}{|c|}{$\begin{array}{c}\text { No. of } \mathrm{His}^{+} \text {revertant colonies } \\
\text { TA98 }\end{array}$} \\
\hline \multirow{5}{*}{$\mathrm{BCP}$} & $\mathrm{mg} /$ plate & $(n=2)$ & $-\quad(n=1)$ \\
\hline & $\mathrm{mg} /$ plate & $24 \pm 6(n=5)$ & $195 \pm 12(n=5)$ \\
\hline & $1 \mathrm{mg} /$ plate & $36 \pm 7(\mathrm{n}=5)$ & $253 \pm 46(n=9)$ \\
\hline & $0.1 \mathrm{mg} /$ plate & $42 \pm 8(n=5)$ & $254 \pm 45(n=9)$ \\
\hline & $0.01 \mathrm{mg} /$ plate & $38 \pm 4(n=5)$ & $255 \pm 18(n=5)$ \\
\hline 2-Aminoanthracene (positive control) & $0.5 \mu \mathrm{g} /$ plate & $196 \pm 76(\mathrm{n}=5)^{*}$ & $334 \pm 41(n=5)^{*}$ \\
\hline DMSO (negative control) & $\mu 1 /$ plate & $37 \pm 9(n=5)$ & $213 \pm 25(n=5)$ \\
\hline
\end{tabular}

No significant difference is found between $0.01 \sim 1 \mathrm{mg} /$ plate of BCP and DMSO in each strain.

Values are mean \pm S.D., *; Statistical difference from control $(p<0.05)$

Table 8 Score of dermal sensitization of BCP in adjuvant and patch test

\begin{tabular}{|c|c|c|c|c|c|c|c|}
\hline & \multirow{3}{*}{$\begin{array}{l}\text { Challenge } \\
\text { conc. (\%) }\end{array}$} & \multicolumn{3}{|c|}{$24 \mathrm{hrs}$} & \multicolumn{3}{|c|}{$48 \mathrm{hrs}$} \\
\hline & & \multicolumn{2}{|c|}{ FR } & \multirow[t]{2}{*}{$\mathrm{MR}$} & \multicolumn{2}{|c|}{ FR } & \multirow[t]{2}{*}{ MR } \\
\hline & & Erythema & Edema & & Erythema & Edema & \\
\hline \multirow{4}{*}{$\mathrm{BCP}$} & 50 & $0 / 3$ & $0 / 3$ & 0.0 & $0 / 3$ & $0 / 3$ & 0.0 \\
\hline & 25 & $0 / 3$ & $0 / 3$ & 0.0 & $0 / 3$ & $0 / 3$ & 0.0 \\
\hline & 10 & $0 / 3$ & $0 / 3$ & 0.0 & $0 / 3$ & $0 / 3$ & 0.0 \\
\hline & 2.5 & $0 / 3$ & $0 / 3$ & 0.0 & $0 / 3$ & $0 / 3$ & 0.0 \\
\hline \multirow{4}{*}{$\begin{array}{l}\text { Positive Control } \\
\text { (Sudan I ) }\end{array}$} & 0.1 & $2 / 2$ & $2 / 2$ & 4.0 & $2 / 2$ & $0 / 2$ & 2.0 \\
\hline & 0.01 & $2 / 2$ & $2 / 2$ & 2.0 & $2 / 2$ & $0 / 2$ & 1.5 \\
\hline & 0.001 & $0 / 2$ & $0 / 2$ & 0.0 & $0 / 2$ & $0 / 2$ & 0.0 \\
\hline & 0.0001 & $0 / 2$ & $0 / 2$ & 0.0 & $0 / 2$ & $0 / 2$ & 0.0 \\
\hline Negative Control (Acetone) & 100 & $0 / 2$ & $0 / 2$ & 0.0 & $0 / 2$ & $0 / 2$ & 0.0 \\
\hline
\end{tabular}

Challenge: Reaction-inducing

FR: Fraction response (= positive/total)

MR: Mean response

compared with the number of negative control. Any dose of BCP resulted in insignificant induction of $\mathrm{His}^{+}$revertant colonies (Table 7).

From the above, no mutagenic effect of BCP was detected in both inductions of frameshift mutations in TA100 and base pair substitutions in TA98.

IV Dermal sensitization test

The result of the test was shown in Table 8. No positive reaction was found in any animal applied BCP of any concentration either $24 \mathrm{hrs}$ or $48 \mathrm{hrs}$ after challenge administration. 


\section{DISCUSSION}

Firstly BCP was compared on cytotoxicity with Canals ${ }^{\circledR}$ and Canals- $\mathrm{N}^{\circledR}$, both of which were useful commercial products in endodontic practice. The base of Canals ${ }^{\circledR}$ is zinceugenol produced by chelating reaction between eugenol and zinc oxide ${ }^{4}$. Occasionally, Canals $^{\mathbb{R}}$ gave irritation to the teeth, and it is comprehensible that the adverse effect of irritation is mainly due to eugenol remaining unchanged in the base ${ }^{18,19)}$. Canals- $\mathrm{N}^{\circledR}$, a non-eugenol type paste consisting of zinc oxide and a mixture of fatty acid and propylene glycol, was invented to get a less-irritative paste. Actually it was admitted that Canals- $\mathrm{N}^{\circledR}$ gave the patients less trouble of irritation and characteristic odor than a zinc-eugenol type paste such as Canals ${ }^{\mathbb{R} 18,19)}$. Then the result of our cytotoxicity test coincided with degrees of adverse effect in clinical practice, because it was shown that cell growth inhibition in vitro by Canals- $\mathrm{N}^{\circledR}$ was much less than by Canals ${ }^{\circledR}$.

It was found that $\mathrm{BCP}$ was as cytotoxic as Canals- $\mathrm{N}^{\circledR}$, and much less than Canals ${ }^{\circledR}$. Cytotoxicity ratio of $\mathrm{BCP}$ to Canals ${ }^{\circledR}$ was about $1 / 6$ as estimated on the basis of $\mathrm{IC}_{50}$ values. These results suggested that irritation of human tissue caused by $\mathrm{BCP}$ might not be more serious than by Canals- $\mathrm{N}^{\circledR}$ and much milder than by Canals ${ }^{\circledR}$. Therefore, it was considered that adverse effect of BCP on human teeth would be within a permissible limit in the clinical practice.

Objective of single dose toxicity study was to elucidate toxicity of BCP given by enforced oral administration to mice. $\mathrm{BCP}$ was given in a dose of $1.0 \mathrm{~g} / \mathrm{kg}$, because we had confirmed through our preliminary test that possible dose in mice was maximal $1.0 \mathrm{~g} / \mathrm{kg}$ for skilful procedure of oral administration.

It was reported that mean body weight of ICR-strain male mice was $28.0 \mathrm{~g}$ (S.D.1.1, $\mathrm{n}=30$ ), $30.7 \mathrm{~g}$ (S.D.1.3, $\mathrm{n}=30$ ) and $32.5 \mathrm{~g}($ S.D.1.5, $\mathrm{n}=30)$ on $35^{\text {th }}, 42^{\text {nd }}$ and $49^{\text {th }}$ day respectively ${ }^{20)}$. The mice of BCP group showed rather better growth (Table 2). It was possible that better growth was brought about by olive oil used as a vehicle of BCP. There was no significant difference on the body weight gain between BCP and control groups. Not only on the body weight gain, but also on D.C., dietary efficacy, W.C., general condition and findings of necropsy, no significant difference was found between $\mathrm{BCP}$ and control groups. No change was seen in macroscopical comparison with the control, while a little decrease in relative liver weight was found in the $\mathrm{BCP}$ group. Also in histopathological examination no difference in liver as well as in kidney could be found between the BCP group and the control. Though a possibility of slight inflammation was shown by partial appearance of infiltrating cells in some specimens of both organs in the both groups, its cause was not clarified in this study.

It is estimated without doubt that oral $\mathrm{LD}_{50}$ in mice was much higher than $1.0 \mathrm{~g} / \mathrm{kg}$, in which dose BCP caused neither death nor any toxic sign of the test animals as mentioned above. According to tabulation of toxicity classes by Deichmann et.al ${ }^{21}$ chemicals or drugs with LD50 of $0.5-5 \mathrm{~g} / \mathrm{kg}$ were graduated into a class of "slightly toxic". When calculated in 
term of a human weighing $50 \mathrm{~kg}, \mathrm{BCP}$ dose of $1.0 \mathrm{~g} / \mathrm{kg}$ was $50 \mathrm{~g}$ which was too high amount to be accidentally taken. Fifty grams of BCP was equivalent to the amount of $200-500$ folds as a dose of dental application into a human tooth. Therefore, it could be hardly considered that proper application of BCP in endodontic therapy gave the dental patients any systemic toxicity.

A mutagenicity test with use of microbe had been developed and demonstrated to be useful means for short-term screening of carcinogen. There was found a little possibility that BCP had mutagenicity, as the findings of the test on BCP were negative.

BCP even in high concentrations of $50 \%$ showed negative results also in the dermal sensitization test, while BCP contained rosin, which showed positive effect alone in the same sensitization test $\mathrm{t}^{17}$. It was understandable that concentration of rosin in BCP paste was about $2.2 \%$ as shown in Table 1 , and it was not enough to cause sensitization, as rosin tested singularly showed a positive effect in concentration above $2.5 \%$.

\section{CONCLUSION}

BCP, a newly developed endodontic paste with thymol of exceptionally high content, was examined on its toxicities by the basic biological tests. Cytotoxicity of BCP was much less than that of Canals which had legal approval of dental use. BCP was clarified less than 'slightly toxic' on systemic toxicity and showed neither mutagenicity nor allergenicity. It was confirmed from the results that $\mathrm{BCP}$ was safe in so far as it was used properly for dental therapy.

\section{REFERENCES}

1) The Association on Japanese official documents: Annotation of Japanese pharmacopeia $6^{\text {th }}$ ed., Hirokawa Publishing Co. Tokyo, 1960, 719-773.

2 ) Editorial board of Japanese pharmacopeia: Annotated edition of Japanese pharmacopeia $14^{\text {th }}$ ed., Hirokawa Publishing Co. Tokyo, 2001, D749-D754, D1125-D1129.

3 ) Hirata, T.: Dental pharmaceutics, Nagasue Publishing Co. Kyoto, 1956, 111-154.

4 ) Yoko, N.: Dental pharmaceutics, Shorin Co. Tokyo, 1992, 153-255.

5 ) Nagasawa, W. and Kawano, Y.: Dental therapy and remedies. Medical Journal Co., Osaka, 1986, 213-273.

6 ) Kuroki, K., Ohsumi, T., Higashi, S., Katsuta, T., Koga, Y. and Soh, Y.: Evaluation of essential oils and thymol used for dental formulae. J. Kyushu Dent. Soc. 58: 63-73, 2004.

7) Takubo, M., Hada, H., Kawahara, S., Ueda, T., Ikeda, M. and Shiozuka, T.: The new concept in endodontics (1). Quintessence 5: 949-963, 1986.

8 ) Takubo, M., Hada, H., Kawahara, S., Ueda, T., Ikeda, M. and Shiozuka, T.: The new concept in endodontics (2). Quintessence 5: 1129-1145, 1986.

9) Watanabe, T. and Horiuchi, S.: Guideline for toxicity studies of drugs and GLP standard. Chijinshokan Co. Tokyo, 1991, 7-52.

10) Satoh, Y. and Sakurai, Y.: Method of safety evaluation of bio-materials for medical and dental use. Science Forum Co. Ltd. Tokyo, 1987, 36-46.

11) Ohsumi, T., Higashi, S., Soh, Y. and Kuroki, K.: A study on antimicrobial efficacy and toxicities of five preparations used for endodontic treatment. J. Kyushu Dent. Soc. 47: 435-442, 1993. 
12) Division of pharmaceutical affairs, Japanese Ministry of Health and Welfare: Manual of Guidelines for non-clinical studies required for approval to manufacture drugs. Yakujinippou Co. Ltd. Tokyo, 1991, 8-19, 93-96.

13) Isidate, M.: Mutagenicity and genotoxicity. Chijinshokan Co. Tokyo, 1991, 1-8, 31-42.

14) Yahagi, T.: Screening methods using microbes for the environmental carcinogens. Tanpakushitsu Kakusan Koso 20: 1178-1189, 1975.

15) Yahagi, T., Degawa, M., Seino, Y., Matsushima, T. and Nagao, M.: Mutagenicity of carcinogenic azo dyes and their derivatives. Cancer Lett. 1: 91-96, 1975.

16) Sato, Y., Katsumura, Y., Ichikawa, H., Kobayashi, T., Kozuka, T., Morikawa, F. and Ohta, S.: A modified technique of guinea pig testing to identify delayed hypersensitivity allergens. Contact Derm. 7: 225-237, 1981.

17) Katuta, T. and Ohsumi, T.: A pharmacological and immuno-pharmacological study on allergic reaction induced by rosin. J. Oral Therap. Pharmacol. 20:11-22, 2001.

18) Ohsumi, T., Kuroki, K., Yuzuriha, T. and Murakami, Y.: Inflammatory potential of essential oils used for endodontic treatment. J. Kyushu Dent. Soc. 40: 436-442, 1986.

19) Ohsumi, T., Higashi, S., Ozumi, K. and Kuroki, K.: Study on allergic contact dermatitis of eugenol in guinea pig. J. Oral Therap. Pharmacol. 15: 63-68, 1996.

20) Japan Charles River Co. Ltd.: Hematological and Urinalysis values of $\mathrm{Crj}$ : $\mathrm{CD}-1$ (ICR) strain mice. The House papers of Japan Charles River Co. Ltd 1985, 1-15.

21) Deichmann W. B. and Gerarde H.W.: Toxicology of drugs and chemicals. Academic Press, New York, 1969, Acolophon page.

\title{
高濃度チモール含有根管充填材の基礎的研究
}

\author{
東 泉 ${ }^{1}$ 大 住 伴 子 $^{1}$ - 古 賀 裕紀子 ${ }^{1}$ \\ 黒木 賀代子' 1 - 福山 宏 \\ ${ }^{1}$ 九州歯科大学健康増進学講座口腔応用薬理学分野 \\ ${ }^{2}$ 九州歯科大学生命科学講座口腔病態病理学分野
}

抄録

超音波バイオメカニカルオブチュレーションシステムに使用する新規開発根管充填材であり，優れた抗菌作用を発 現するチモールを含有している Biological canal paste (BCP) の安全性評価を行った. 生物学的基礎試験として, 細胞毒性, 全身毒性, 変異原性, および感作性を調べた. BCP の細胞增殖阻止力は, Canals- $\mathrm{N}^{\circledR}$ と同程度で Canals ${ }^{\circledR}$ より小さかった． BCP の投与可能な最大量である $1.0 \mathrm{mg} / \mathrm{kg}$ のマゥスへの投与により，死亡例はなく毒性症状む認 められなかったことから， BCP の $\mathrm{LD}_{50}$ は高くDeichmannによる毒性分類表での「わずかに毒性がある」の範囲以 上と考えられた. Ames 試験による変異原性試験およびモルモットを用いた感作性試験において，BCP は陰性で あった，これらの結果から，BCP は歯科治療に用いる上では安全である可能性が示唆された.

$$
\text { キーワード : BCP/チモール/毒性 }
$$

